\title{
One image, two stories: Ethnographic and touristic photography and the practice of craft in Mexico
}

Article

Accepted Version

Cant, A. (2015) One image, two stories: Ethnographic and touristic photography and the practice of craft in Mexico.

Visual Anthropology, 28 (4). pp. 277-285. ISSN 0894-9468 doi: https://doi.org/10.1080/08949468.2015.1052308 Available at https://centaur.reading.ac.uk/86152/

It is advisable to refer to the publisher's version if you intend to cite from the work. See Guidance on citing.

To link to this article DOI: http://dx.doi.org/10.1080/08949468.2015.1052308

Publisher: Taylor \& Francis

All outputs in CentAUR are protected by Intellectual Property Rights law, including copyright law. Copyright and IPR is retained by the creators or other copyright holders. Terms and conditions for use of this material are defined in the End User Agreement.

$\underline{\text { www.reading.ac.uk/centaur }}$ 
Central Archive at the University of Reading

Reading's research outputs online 


\section{Cant, Alanna 2015. 'One Image, Two Stories: Ethnographic and Touristic Photography and the Practice of Craft in Mexico' Visual Anthropology 28(4): 277-285.}

Although tourists and ethnographers take photos with different intentions and for different uses, the images they produce may be essentially similar. I explore this matter in reference to a photograph I took during research in Oaxaca, Mexico, one that is also commonly taken by tourists who visit the woodcarving workshops there. While this photo is persuasive within touristic discourses that frame Oaxaca as reflecting authentic indigenous culture, the story it tells within my ethnography is more complicated. In discussing the space between these stories, I suggest that photographs of craft practices may in turn reconstitute artisans' practices themselves.

\section{TOURISTS AND RESEARCHERS}

If one judges such things by the frequency of occurrence, the village of San Martín Tilcajete in the southern Mexican state of Oaxaca is plainly picturesque in the sense meant by William Gilpin, the 18th-century English Romantic painter, who coined the term picturesque to indicate "that peculiar kind of beauty, which is agreeable in a picture" [1792: 19]. It seems many people find San Martín agreeable for their pictures; its dusty streets, colorful buildings and dark-haired children in simple school uniforms seem to easily catch the eyes of tourists, both Mexican and foreign. The workshops of the community's many artisans, the focus of my ethnographic fieldwork in 2008-2009, lend themselves particularly well to picture-taking as carvers and painters work in the dappled sunlight of shaded courtyards and invite tourists to take photos in the hope they will also purchase Oaxacan woodcarvings, or alebrijes, the village's signature product. Other practices of photography also occur here: young artisans themselves photograph their work for websites and business cards; migrants visiting home from the United States snap hundreds of shots of their natal homes and family fiestas; and researchersjournalists, design students and anthropologists like myself-take photographs to illustrate their descriptions and analyses. As these photos are taken with greatly different intentions and motivated by different perspectives, it might be assumed that they are distinct in terms of mood, style and content. Sometimes this is the case. Tourists and journalists, for example, are unlikely to photograph newly installed American washing-machines that have been purchased with migrants' remittances, as one family in San Martín proudly did. Other times, however, these photographic genres begin to converge, producing images that are effectively the same, and leading me to reflect on what photography might mean within the context of my larger project about aesthetic practices in craft economies.

This convergence has been both theoretically stimulating and methodologically challenging for my work. When I returned from the field and began to consider how to represent my research, I realized that much of my photographic data seemed to tell a different story than my words did. While my text sought to critically unpack concepts like authorship, competition, and 
aesthetics, the images that accompanied it were in many cases not dissimilar from what one finds in touristic guidebooks. In reflecting on this point here, I am not directly concerned with photography's larger semiotic or ideological consequences, although of course these questions are not unrelated to the issue. Instead, I want to think through how photographs of craft may directly influence craftwork as they circulate between publics of tourists, art collectors and researchers. The basic question of the political and social power of photography is of course not new. Catherine Lutz and Jane Collins' Reading National Geographic [1993; reviewed in Visual Anthropology, 7(3): 261-269], for example, interrogated these issues thoroughly. However, researchers working specifically on artisanal practices should also extend these questions so as to understand how photographs of craft production may work to constitute these practices themselves. In the following sections, I consider a particular photo that I took during fieldwork, one very commonly taken by tourists and folk-art collectors who visit San Martín. As I will show, while this photo is particularly persuasive within touristic understandings that frame Oaxaca in terms of cultural authenticity, the story it tells within my ethnography is quite a bit more complicated. I suggest that the conceptual space between these stories is a constitutive, if somewhat obscured, terrain on which artisanal production and competition take place. At the end of the article I suggest that addressing this productive space not only allows for theoretical insights into photography and craft practices but also raises questions about ethics and methodology for anthropologists of craft.

\section{TWO STORIES. . .}

Figure 1 is the image that I have found the most problematic to deal with while writing. It is arguably one of the images more frequently photographed by tourists who visit San Martín Tilcajete. It shows the hands of Miguel García,1 the owner of a high-end workshop where delicate and expensive carvings are made for tourists and for export. For most tourists who snap this photo it tells the story of Oaxacan woodcarvings as the natural aesthetic and artisanal expression of a centuries-old rural, indigenous Mexican culture. In the image Miguel's hands are covered in natural paint during a demonstration that he gives to tourists in his large, comfortable workshop. Sitting in the cool shade, visitors learn that these natural dyes have been handed down from his ancestors, the pre-Hispanic Zapotecs: "If you visit the state museum in Oaxaca City," he says, "you will see that the ancient Zapotecs always wrote their codices in three colors: black, yellow and red. We can still make these colors today, using natural plants and minerals."

As Miguel speaks, he uses ingredients like tree sap, lime juice and fungus to transform his hands into a palette of ochre, vermilion and inky black. The demonstration culminates as Miguel crushes juicy red pomegranate seeds into his palm and proceeds to blend in snowy-white powdered limestone, which he explains is also important for making maize tortillas, the staple food of the region. The tourists, tour guide and anthropologist lean in closer in awe as the bright red juice reacts with the white powder, producing a vivid turquoise hue. Before he 
washes his hands Miguel pauses to allow everyone to take pictures, and then introduces the workshop where young women and men paint fine designs in ocher, black and turquoise onto the smooth surfaces of wood.

The Garcías are the only artisans in San Martín who provide a fully developed demonstration for tourists in both English and Spanish, and this has contributed immeasurably to their current status as the most well-known and well-off artisans in the community. As their pieces now sell for many times more than most other Oaxacan woodcarvings, tour guides who work on commission are also more likely to bring clients to their workshop, exponentially increasing the number of visitors who see Miguel's demonstration and have the opportunity to photograph his hands. The effectiveness of this demonstration in terms of producing cultural authority and authenticity is due to the powerful combination of materials and performance; within this context the image of Miguel's hands covered with natural paint becomes particularly persuasive, as the visitors themselves witness the production of natural pigments, which they are told are part of local indigenous knowledge.

The persuasiveness of this story of the image is further bolstered in two ways. First, it fits neatly within Oaxaca's state-led tourism program that promotes craftwork through tropes of authenticity and tradition that link contemporary craft production to distinct indigenous cultural identities [Brulotte 2012: 146-150; Wood 2008: 31-76]. Secondly, it is reinforced by the generalized public dissemination of the image through processes recently described by Martin Hand as "photographic ubiquity" [2012]. Hand suggests that in the current period of digital- and internet-driven photography, images are qualitatively distinct from earlier types, both because of the increased public exposure of non-professional photographs in media and society and their increasingly networked nature, that is, the way that the same or similar images are simultaneously located in many different places, media and messages, often with digital links that connect them [ibid.: 12, 25-30]. Photographic ubiquity is a central component of how authenticity is produced and interpreted in tourism locales, as tourists often seek out what they have already seen in books and on television [Urry 1990], and more recently on the internet. Tourists use the internet to plan their holidays and often post images of their travels, both semi-publicly and publicly online. Through such practices tourists' private photography now forms part of the marketing and information landscape in which artisans and other cultural producers work. I recently did an internet search of the words "Tilcajete, paint, woodcarvings": of the first 100 images displayed, twenty were clearly from the Garcías' workshop and five of these showed Miguel or his wife Catalina's hands covered with paint. They were from websites ranging from travelers' personal blogs and non-profit organizations to American news magazines and the Garcías' own website. The multiplicity of this image in location, media and authorship underscores its authority as evidence by drawing on expectations that equate repetition and truth (what psychologists call "confirmation bias"). These photo-scapes also now influence non-visiting consumers like American folk-art collectors, as artisans and wholesalers increasingly sell work online [Chibnik 2008]. 
While the ubiquity of the image of Miguel's hands is in itself interesting anthropological data, I want to contrast the touristic account it visually reinforces with the story that this image portrays in my own writing. Instead of illustrating the cultural roots of Oaxacan woodcarving practices and materials, the picture of Miguel's hands illustrates to me a story of how the Garcías intentionally incorporate tourists' and collectors' understandings of indigenous culture and authenticity into their aesthetic and discursive practices, within a larger context of tense economic precarity and competition in San Martín Tilcajete. Significantly, the Garcías' explanation that links Oaxacan woodcarving to ancient Zapotec culture sits uncomfortably with other local and academic understandings that describe a much shorter history of the craft. In his ethnographic study of the three major Oaxacan woodcarving communities in the 1990s, Michael Chibnik describes how the craft got started in the 1950s when Manuel Jimenez, a peasant farmer from the village of Arrazola near Oaxaca City, began selling carved masks and small sculptures to vendors in the city market. The woodcarvings did not begin to be produced in San Martín until as recently as the late 1970s, when a resident of the village became the local manager of a federal craft purchasing program. He encouraged some of his neighbors to produce carvings which he then bought for the government stores. It was only by the late 1980s that woodcarving was established as a significant occupation in San Martín Tilcajete [Chibnik 2003: 27-30, 32-34].

Chibnik observes that in the 1990s he never heard any artisans identify themselves as either "Indians" or "Zapotecs." By 2008 some residents of San Martín expressed an increased interest in indigeneity and their Zapotec ancestors whose ruins perch on a hillside above the village [Cant 2012: 245-285]. This change is connected to their experiences of cultural tourism, which disseminates a more positive image of indigeneity than those that generally circulate in Oaxaca and Mexico. While there may be many constructive outcomes of this process, a direct link between woodcarvings and Zapotec heritage is still not held by most artisans. The majority continue to explain Oaxacan woodcarving as a recent craft form, and most will explicitly cite Manuel Jimenez as its originator. Miguel García acknowledges Jimenez as an important character in the history of the craft, but often describes him as a gran maestro (great master) of Oaxacan woodcarving rather than its originator. During demonstrations he frequently avoids discussing Jimenez or the other woodcarving villages at all, preferring instead to play on the ambiguities present in local touristic discourses that connect autochthony and "nativeness" to the long-standing cultural continuity assumed to be present in the region's craft traditions [Brulotte 2012: 146-150; Cant 2012: 49-65; Wood 2008: 31-76]. While the two explanations need not be mutually exclusive in principle, the increasing legitimacy of the Garcías' claims that the woodcarvings originated in ancient Zapotec material production is becoming an authoritative account of the history and meaning of woodcarvings.

Within San Martín the increasing authority of the touristic reading of "Miguel's Hands" presents a challenge to other artisans. While many of their neighbors might also be interested in exploring indigeneity through their artistic work, most have not had nearly as much experience as the Garcías in the North American ethnic art world that values indigenous art 
highly. Over the past ten years they have become experts in "selling culture," and are now skilled in the language of this art world, securing their privileged position within this important market. In addition to their verbal accounts which connect the carvings to indigenous identity, they have also increasingly tailored the aesthetics of their work to fit with this market's expectations - they now include symbols, forms and color combinations that are easily read as "indigenous" by those familiar with the art of other Native American groups, and they refer to their forms of carving and painting explicitly as the "Zapotec style" [Figure 2]. While this approach has been very successful for the Garcías themselves, it also works to marginalize other Oaxacan artisans whose work is less connectable to claims of indigenous belonging [Cant, forthcoming].

Longer-established styles of woodcarving are more consistent with Oaxacan and Mexican popular culture than a specifically indigenous aesthetic. They are often figures from the folktales of the countryside and popular Catholicism, like skeletons and saints or imaginative animal forms. They are normally painted in glossy acrylic paint in the bright hues and patterns that are associated with Mexico more generally, and do not reference the overt symbols of indigeneity that the Garcías have incorporated into their work. While many artisans have developed their own unique styles in carving and painting, there remains an overall aesthetic consistency amongst most Oaxacan woodcarvings, which are distinctly different from what the Garcías produce. While most artisans I knew in San Martín appreciated the obvious talent and skill that the Garcías' work evidenced, some were uncomfortable about the unequivocal connection they claimed between woodcarving and the village's Zapotec past. Some complained that this obscured the roles that the earliest carvers in San Martín had played in establishing the craft, while others were annoyed that the Garcías appeared to use the village itself as a resource in a way that did not benefit everyone.

\section{... .AND THE PRACTICE OF CRAFT}

Thus far I have described the two different stories that the image of Miguel's hands tells about Oaxacan woodcarvings. To the tourists and collectors who visit the Garcías' workshop or encounter this image online or in the popular press, it is often considered evidence of an ongoing cultural, material, aesthetic and sometimes spiritual connection between contemporary artisans and their ancient Zapotec ancestors [Tiffany 2004]. In my ethnography this image instead tells a story of entrepreneurialism, competition and power within a highly saturated market, signifying performance rather than straightforward exposition.2 The sharp contrast between the two stories raises the issue of how we should conceptualize the differences between the photographic practices that we encounter in our research, particularly as these differences can have real effects in our research sites. I argue that we may regard the distance between the two stories about Miguel's hands as a dynamic conceptual space where the practices of woodcarving production are currently being renegotiated and transformed. 
While the Garcías' neighbors may complain in principle about their increasing assertions of the indigenous history of Oaxacan woodcarvings, they are also aware that this discourse draws attention to San Martín's craftwork in general, and many feel that they cannot afford to discourage interest in Oaxacan woodcarvings. Some also acknowledge that this "indigenization" of the woodcarvings may give San Martín a competitive advantage over the residents of Arrazola, whose ancestry is less straightforwardly connected to particular ancient Zapotec sites. As such, some artisans have sought to bring their work more into line with these newer expectations of tourists and collectors. 3 A number of people in San Martín have begun to incorporate what they see as "Zapotec-like" imagery into the painting on their pieces and have even attempted to replicate the Garcías' particularly complex painting style. One artisan I know admitted that he has gone to the regional museum of popular art specifically to see the Garcías' pieces up close so as to, as he put it, "steal their inspirations." He justified this action by claiming that the Garcías were creating an unfair playing-field by keeping to themselves these ideas that are based on everyone's culture. Indeed, since I finished fieldwork I have noted a number of carvings for sale online by other artisans which clearly replicate the Garcías' distinctive style.

In addition to this shift in stylistic or aesthetic practices, the differences between these stories also generate a space in which understandings about quality of work and materials are redefined. For consumers from places where markets are dominated by industrially produced goods, "natural" products are increasingly assumed to be of higher quality than their industrial counterparts, which is also reflected in the prices that handmade goods and organic food now attract [Paxson 2011]. The natural paints and pigments that Miguel produces in front of tourists' very eyes have now become recognized by some consumers as a marker of quality and desirability, making the bright acrylic paints used by other artisans to appear of lesser quality and therefore less desirable in contrast. This distinction is accentuated by the Garcías' pricing practices, as they charge more money for those pieces painted in natural colors than for the ones they paint in bright acrylics. Apart from their employees and relatives, other artisans are not privy to the details of the Garcías' performance in their workshop, and so it is difficult for them to replicate the multitude of ways that the Garcías add value to their work. Scraps of information do inevitably filter out through connections of kinship and friendship with their employees, and rumors often circulate questioning the honesty of some of the Garcías' practices.

In the introduction to a special volume on evidence in anthropology, Matthew Engelke observes that photographs tend to be used as "external validations" of the texts we write rather than evidence in themselves [2008: 14]. My article suggests this approach to photographic data is not as straightforward as it might appear, as images may carry with them other stories and other kinds of knowledge. While the intended audiences of anthropological literature (other anthropologists) are likely to see them in the ways we anticipate, in an increasingly digital academic environment our work is by no means isolated from the larger processes of knowledge and cultural production about which we write. In my own case, I have been 
particularly concerned about both reproducing and writing critically about the image of Miguel's hands in my work. On the one hand, including this image might contribute to the increasing authority of the Garcías within the world of Mexican folk-art, as it could position it within the legitimizing frame of academic research. As I was aware of the increasing tensions between the Garcías and some of their neighbors, I hoped to avoid contributing to a situation that was considered unfair by many of my other research participants. On the other hand, anthropological explanations of the Garcías" "invention of tradition" could undermine them and other artisans in the eyes of consumers or other important figures within their art world. In his work on Oaxacan textiles, William W. Wood has described how an American ethnic art dealer interpreted his analyses of production and marketing practices, and told his research participants that he was "revealing secrets" that undermined the weavers' claims to authenticity and tradition [Wood 2001]. This is a particularly salient issue in Oaxaca, where the cultural tourism and ethnic art paradigms attract a particular kind of educationally oriented visitor, many of whom read ethnographies easily found in Oaxaca City's English-language bookstore. While it may be impossible ever to completely avoid the kind of representational and ethical issues that this situation presents, it is worth paying attention to how anthropological photographic and analytical practices are also part of the contexts in which our research takes place.

Contemporary practices of craft and photography indeed present many of the same puzzles to anthropologists who investigate them: both forms may raise issues such as authenticity, ownership and the nature of aesthetic commodities in the economies and societies in which they circulate. For anthropologists who research craft, the relationship between these forms may be much more entangled, as photography is both an anthropological method of investigation and representation and one very frequently used by our research participants and other people in their social worlds. I am prompted to suggest that more attention should be paid to how photography itself is involved in the processes that we study. I have argued that in the case of the artisans with whom I work in Mexico, photography actively contributes to the craft practices and art worlds in which they work. Being theoretically concerned with bodily, material and communicative practices, anthropologists working on craft might also be particularly well-placed to address not just what photos do in anthropological field sites, but also what kinds of things they are. Through a deeper consideration of how photographs evidence and contribute to practice, we may also generate new methods for researching the production of craftwork.

\section{NOTES}

1. A pseudonym. 2. This is not to suggest that their involvement in tourism somehow renders artisans' increasing interest in indigeneity false or invalid; but the relationships between these processes are analytically and historically important, especially in regard to this particular 
photograph. 3. This is especially the case for commercial artisans who have not managed to secure for themselves a particular style or "name" within the woodcarving market.

\section{REFERENCES}

Brulotte, Ronda 2012 Between Art and Artifact: Archaeological Replicas and Cultural Production in Oaxaca, Mexico. Austin: University of Texas Press.

Cant, Alanna 2012 Practising Aesthetics: Artisanal Production and Politics in a Woodcarving Village in Oaxaca, Mexico. London: London School of Economics and Political Science; Ph.D. dissertation in Anthropology.

Forthcoming The Art of Indigeneity: Aesthetics and Competition in Mexican Economies of Culture. Ethnos: Journal of Anthropology. Published electronically 30 June 2014.

Chibnik, Michael 2003 Crafting Tradition: The Making and Marketing of Oaxacan Woodcarvings. Austin: University of Texas Press.

2008 Advertising Oaxacan Wood Carvings. Human Organization, 67(4): 362-372.

Engelke, Matthew 2008 The Objects of Evidence. Journal of the Royal Anthropological Institute, 14(S1): S1-S21.

Gilpin, William 1792 An Essay on Prints. London: R. Blamire.

Hand, Martin 2012 Ubiquitous Photography: Digital Media and Society. Cambridge: Polity Press.

Lutz, Catherine A., and Jane L. Collins 1993 Reading National Geographic. Chicago: University of Chicago Press.

Paxson, Heather 2011 The 'Art' and 'Science' of Handcrafting Cheese in the United States. Endeavour, 35(2-3): 116-124.

Tiffany, Sharon 2004 Frame That Rug: Narratives of Zapotec Textiles as Art and Ethnic Commodity in the Global Marketplace. Visual Anthropology, 17: 293-318.

Urry, John 1990 The Tourist Gaze: Leisure and Travel in Contemporary Societies. London: Sage Publications.

Wood, William W. 2001 Rapport Is Overrated: Southwestern Ethnic Art Dealers and Ethnographers in the "Field." Qualitative Inquiry, 7(4): 484-503.

2008 Made in Mexico: Zapotec Weavers and the Global Ethnic Art Market. Indianapolis: University of Indiana Press. 